\title{
Re-Engineering University Education through Strategic Information Management: The Nigerian Experience
}

\author{
Nnenna Ekpereka Ibezim*, Chiaka Augusta Obi \\ Department of Vocational Teacher Education, University of Nigeria, Nsukka, Nigeria \\ Email: *nnenna.ibezim@unn.edu.ng
}

Received October 10, 2013; revised November 10, 2013; accepted November 16, 2013

Copyright (C) 2013 Nnenna Ekpereka Ibezim, Chiaka Augusta Obi. This is an open access article distributed under the Creative Commons Attribution License, which permits unrestricted use, distribution, and reproduction in any medium, provided the original work is properly cited.

\begin{abstract}
The role of information technology in any environment is simple to support the short and long term goals of the organization. In the academic world it means supporting the institution's mission, vision, and goals articulated in its strategic plan. The final result of any strategic plan is typically a set of high-level objectives that contain specific goals with detailed timelines for their completion. This study was carried out to ascertain the Nigerian experience in re-engineering university education through strategic information management. To achieve this objective, three research questions and one hypothesis were formulated, answered and tested respectively. Survey research design was used and a structured questionnaire was developed for data collection. A population of 330 information managers in information system units in federal universities in Nigeria was used for the study. The questionnaire was face-validated by three experts knowledgeable in strategic information management. An internal consistency co-efficient of 0.88 was obtained by using Cronbach alpha technique. Data collected from 322 of the respondents were analyzed for the study. Mean and standard deviation were used in data analysis, while ANOVA was used to test the hypothesis. The findings of the study revealed vital processes in teaching/learning, research, and university administration that despite the investments on information management in the universities, have not been re-engineered through strategic information management to a great extent.
\end{abstract}

Keywords: Strategic Information Management; Re-Engineering; University Education

\section{Introduction}

Strategic management is the art and science of formulating, implementing and evaluating cross-functional decisions that will enable an organization to achieve its objectives [1]. It is the process of specifying the organization's objectives, developing policies and plans to achieve these objectives, and allocating resources to implement the policies and plans to achieve the organization's objectives. Strategic management, therefore, combines the activities of the various functional areas of a business to achieve organizational objectives. It is the highest level of managerial activity, usually formulated by the board of directors and performed by the organization's chief executive officer (CEO) and executive team.

Strategic information systems on the other hand are those computer systems that implement business strategies. As opined by Shirazi and Soroor [2], they are those systems where information services resources are applied

"Corresponding author. to strategic business opportunities in such a way that the computer systems have an impact on the organization's products and business operations. Strategic information systems are always systems that are developed in response to corporate business initiative. The ideas in several well-known cases came from information services people, but they were directed at specific corporate business thrusts. In other cases, the ideas came from business operational people, and Information Services supplied the technological capabilities to realize profitable results. Most information systems are looked on as support activities to the business. They mechanize operations for better efficiency, control, and effectiveness, but they do not, in themselves, increase corporate profitability. They are simply used to provide management with sufficient dependable information to keep the business running smoothly, and they are used for analysis to plan new directions. Strategic information systems, thus, become an integral and necessary part of any business, and directly influence market share, earnings, and all other aspects of 
marketplace profitability. They may even bring in new products, new markets, and new ways of doing business. They directly affect the competitive stance of the organization, giving it an advantage against the competitors [3]. Furthermore, strategic systems are those that link business and computer strategies. They may be systems where a new business thrust has been envisioned and its advantages can be best realized through the use of information technology. They may be systems where new computer technology has been made available on the market, and planners with an entrepreneurial spirit perceive how the new capabilities can quickly gain competitive advantages. They may be systems where operational management people and Information Services people have brainstormed together over business problems, and have realized that a new competitive thrust is possible when computer methods are applied in a new way [4].

Information systems can be viewed strategically as competitive networks, as a means of organizational renewal, and as a vital investment in technologies that help an enterprise achieve its strategic objectives. According to O'Brien [5], the strategic role of information systems involves using information technology to develop products, services, and capabilities that give a company strategic advantages over the competitive forces it faces in the global market place. So, a strategic information system can be any kind of information system that helps an organization gain a competitive advantage, reduce competitive disadvantages, or meet other strategic enterprise objectives.

The role of information technology in any environment is simple to support the short and long term goals of the organization. In the academic world it means supporting the institution's mission, vision, and goals articulated in its strategic plan. The final result of any strategic plan is typically a set of high-level objectives that contain specific goals with detailed timelines for their completion [6]. University education is directed by distinct objectives. According to Massy [7] high-quality undergraduate education is just one of the objectives of colleges and universities; research and graduate education and, for some institutions, public services also are important. Fulfilling these objectives in university education is a great challenge; it imposes specific demands, not only on scientific content but also on teachers and teaching methods. Teaching must stimulate students to learn, to seek information and to critically synthesize information and knowledge, also to offer possibilities for applying acquired skills [8]. This means a re-engineering of the teaching methods and information management/ technology used.

The concept of re-engineering according to Hammer and Champy in Business Dictionary [9] is a fundamental rethinking and radical redesign of business process to achieve dramatic improvements in critical measures of performance such as cost, service, and speed. It is systematic to start over and reinvent the way with which a firm, or a business process, gets its work done. It is also the analysis and design of workflows and processes within and between organizations [9]. As stated by Hammer \& Champy [10], Information technology (IT) has historically played an important role in the reengineering concept. It is considered by some as a major enabler for new forms of working and collaborating within an organization and across organizational borders.

Consequently, Abdous and He [11], opined that in spite of academics' often skeptical stance against business process re-engineering, and other management concepts, which may seem foreign to the organizational culture of higher education, many universities have reengineered their internal processes. Higher Education institutions have invested heavily in business process reengineering, leveraging information technology to improve services and reduce costs. Higher institutions in Nigeria are not left out, thus, as they faced the challenges of the $21^{\text {st }}$ century, it became imperative to rely on the power of computer-based information systems for efficient delivery of services in a cost-effective manner. This interest in rethinking processes and procedures is driven mainly by budget shortfalls, information technology infusion, and external pressures for greater accountability and responsiveness [12]. Despite this enthusiasm and heavy investment from Higher Education institutions in Nigeria, the universities have never been able to achieve the kind of result they desired [13]. It is against this background that this study sought to assess the extent to which Nigerian universities utilize strategic information management to re-engineer the academic processes for better results, in order to detect the loop holes and determine the areas that need improvement or more attention. Specifically, an attempt was made to determine the extent to which strategic information management is used to re-engineer:

1). Teaching and Learning

2). Research

3). University Administration

\section{Hypothesis}

There is no significant difference in the mean responses of information managers in the federal universities in $\mathrm{Ni}$ geria on the extent to which strategic information management is used to re-engineer university education.

\section{Methods}

The survey research design was adopted for the study. The study was conducted in the federal universities with Information Systems (IS) units in the six geopolitical zones of Nigeria. The population was 520 information 
managers from the 25 federal universities with Information Systems (IS) units. A sample size of 330 information managers obtained through a multi-stage sampling technique by selecting two universities from each of the six geo-political zones of Nigeria was used for the study and was distributed as follows: 52 from North West, 77 from South East, 35 from South West, 50 from North Central, 67 from South South, and 49 from North East. The instrument for data collection was a structured questionnaire on a 4-point scale as follows: Very Great Extent (VGE), Great Extent (GE), Moderate Extent (ME), Little Extent (LE), and Very Little Extent (VLE) with weightings of $5,4,3,2$, and 1 respectively. The questionnaire was face-validated by three experts and the Cronbach alpha technique was used to determine the internal consistency of the instrument, which yielded a coefficient of 0.88 .

The weighted mean was used to answer the research questions. The mean of the items was interpreted in relation to the real limit of numbers of the rating scale used for data analysis. Items with means ranging from 4.5 5.00 are utilized in a very great extent, those with means ranging from 3.5 - 4.00 are utilized in a great extent; the items with means ranging from 2.5 - 3.49 are utilized in a moderate extent; those with mean ranges between 1.5 2.49 are utilized in a little extent; and items with mean ranging from 0.5 - 1.49 are utilized in a very little extent. ANOVA statistic was used to test the null hypothesis. The null hypothesis of no significant difference was accepted where F-calculated was less than the F-table values respectively at 0.05 level of significance at appropriate degrees of freedom and was rejected if otherwise.
The standard deviation was used to determine the closeness or otherwise of the responses of the respondents to the mean. Any item with a low standard deviation indicated that there were less variations in the responses of the respondents, indicating that the mean values of the items were valid.

\section{Results}

The results of the study were obtained from the research questions answered and hypothesis tested as shown in Tables 1-3.

\section{Research Question 1}

To what extent is strategic information management utilized in re-engineering teaching and learning in federal universities in Nigeria?

The data for answering the research question and testing the hypothesis are presented in Table $\mathbf{1 .}$

Table 1 shows that item 7 had a mean value of 3.67 indicating that the universities utilize IT to strategically re-engineer admission services to a great extent. Seven items had their mean values ranging from 2.95 - 3.49 indicating that the universities utilize strategic information management to re-engineer those items to a moderate extent. Items 3,5 , and 8 had mean values of 2.40 , 2.48 and 2.06 respectively showing that the universities utilize strategic information management to re-engineer these items to a little extent.

Data in Table 1 further revealed that 6 items had their f-calculated less than the f-table value (3.09), showing that for those items, the null hypothesis of no significance was accepted, while it was rejected for the remaining 5 items whose f-calculated values was greater than the f-table values.

Table 1. Respondents Mean Scores and Analysis of Variance (ANOVA) on the extent to which strategic information management is utilized in re-engineering teaching and learning in federal universities in Nigeria.

\begin{tabular}{|c|c|c|c|c|c|c|}
\hline \multirow{2}{*}{$\mathbf{S} / \mathbf{N}$} & \multirow{2}{*}{ Use of Information Technology to: } & \multirow{2}{*}{$\overline{\mathbf{X}}$} & \multirow{2}{*}{ SD } & \multirow{2}{*}{ F-cal } & \multicolumn{2}{|c|}{ Remarks } \\
\hline & & & & & $\mathbf{R Q}$ & Ho \\
\hline 1. & Produce learning aids/objects & 3.22 & 1.23 & 2.53 & Moderate Extent & NS \\
\hline 2. & Produce and present lecture notes & 3.35 & 1.22 & 2.74 & Moderate Extent & NS \\
\hline 3. & Carry out and submit academic assignment & 2.40 & 0.79 & 4.13 & Little Extent & $\mathrm{S}$ \\
\hline 4. & Publish academic achievement & 3.40 & 1.19 & 2.54 & Moderate Extent & NS \\
\hline 5. & Compute/process student's results & 2.48 & 1.24 & 6.17 & Little Extent & S \\
\hline 6. & Provide student registration services & 3.33 & 1.24 & 5.26 & Moderate Extent & $\mathrm{S}$ \\
\hline 7. & Provide admission services & 3.67 & 1.14 & 3.00 & Great Extent & NS \\
\hline 8. & Use ICTs in teaching & 2.06 & 0.56 & 3.81. & Little Extent & $\mathrm{S}$ \\
\hline 9. & Provide internet services for learning materials & 3.36 & 0.49 & 3.00 & Moderate Extent & NS \\
\hline 10. & Improve the quality of academic work. & 3.49 & 1.19 & 2.74 & Moderate Extent & NS \\
\hline 11. & $\begin{array}{l}\text { Substantially shorten time needed to develop, } \\
\text { produce, and deliver products and services }\end{array}$ & 2.95 & 1.16 & 4.05 & Moderate Extent & $\mathrm{S}$ \\
\hline
\end{tabular}

F-tab $=3.09, \mathrm{df}=2$ and 319, $\mathrm{P}>0.05$. 
Table 2. Respondents Mean Scores and Analysis of Variance (ANOVA) on the extent to which strategic information management is utilized in re-engineering research in federal universities in Nigeria.

\begin{tabular}{|c|c|c|c|c|c|c|}
\hline \multirow{2}{*}{$\mathbf{S} / \mathbf{N}$} & \multirow{2}{*}{ Use of Information Technology to: } & \multirow{2}{*}{$\overline{\mathbf{X}}$} & \multirow{2}{*}{ SD } & \multirow{2}{*}{ F-cal } & \multicolumn{2}{|l|}{ Remarks } \\
\hline & & & & & $\mathbf{R Q}$ & Ho \\
\hline 1. & Provide internet services for research works & 3.25 & 1.11 & 1.15 & Moderate Extent & NS \\
\hline 2. & $\begin{array}{l}\text { Provide conducive environments for scientific } \\
\text { researches }\end{array}$ & 3.39 & 1.12 & 1.12 & Moderate Extent & NS \\
\hline 3. & Provide Library services for researches & 3.27 & 1.23 & 3.13 & Moderate Extent & $\mathrm{S}$ \\
\hline 4. & $\begin{array}{c}\text { Create virtual organizations for academic and } \\
\text { research works }\end{array}$ & 2.48 & 1.22 & 2.54 & Little Extent & NS \\
\hline 5. & Publish research products & 3.41 & 0.86 & 5.17 & Moderate Extent & $\mathrm{S}$ \\
\hline 6. & $\begin{array}{l}\text { Provide Scientific Laboratory } \\
\text { equipment/resources }\end{array}$ & 2.95 & 1.10 & 4.26 & Moderate Extent & $\mathrm{S}$ \\
\hline 7. & Collaborate with foreign researchers & 2.03 & 1.24 & 3.51. & Little Extent & $\mathrm{S}$ \\
\hline 8. & Provide capacity building for research work & 3.75 & 1.14 & 2.50 & Great Extent & NS \\
\hline 9. & Develop research proposals/teams & 3.46 & 1.08 & 3.02 & Moderate Extent & NS \\
\hline 10. & $\begin{array}{l}\text { Develop new unique markets for research } \\
\text { products }\end{array}$ & 2.46 & 1.09 & 2.70 & Little Extent & NS \\
\hline
\end{tabular}

F-tab $=3.09, \mathrm{df}=2$ and $319, \mathrm{P}>0.05$.

Table 3. Respondents Mean Scores and Analysis of Variance (ANOVA) on the extent to which strategic information management is utilized in re-engineering university administration in federal universities in Nigeria.

\begin{tabular}{|c|c|c|c|c|c|c|}
\hline \multirow{2}{*}{$\mathbf{S} / \mathbf{N}$} & \multirow{2}{*}{ Use of Information Technology to: } & \multirow{2}{*}{$\overline{\mathbf{X}}$} & \multirow{2}{*}{ SD } & \multirow{2}{*}{ F-cal } & \multicolumn{2}{|c|}{ Remarks } \\
\hline & & & & & RQ & Нo \\
\hline 1. & Promote administrative objectives & 3.39 & 1.22 & 2.30 & Moderate Extent & NS \\
\hline 2. & $\begin{array}{l}\text { Provide new relationships with clients of the } \\
\text { institution }\end{array}$ & 3.36 & 1.25 & 2.38 & Moderate Extent & NS \\
\hline 3. & $\begin{array}{l}\text { Discourage clients from switching to other } \\
\text { institutions }\end{array}$ & 3.22 & 1.23 & 2.15 & Moderate Extent & NS \\
\hline 4. & Re-engineer administrative operations & 3.33 & 1.24 & 2.54 & Moderate Extent & NS \\
\hline 5. & $\begin{array}{l}\text { Institute unique institutional } \\
\text { reformations/innovations }\end{array}$ & 3.49 & 1.24 & 3.17 & Moderate Extent & $\mathrm{S}$ \\
\hline 6. & Capture and keep administrative records & 3.45 & 1.05 & 2.26 & Moderate Extent & NS \\
\hline 7. & Involve IT products in decision making & 3.39 & 1.11 & 2.50 & Moderate Extent & NS \\
\hline 9. & Create security networks within the institution & 3.46 & 1.08 & 3.10 & Moderate Extent & $\mathrm{S}$ \\
\hline
\end{tabular}

F-tab $=3.09$, df $=2$ and 319, $\mathrm{P}>0.05$.

The Table also showed that the standard deviation of the items ranged from $0.49-1.24$ which is a low range of values, indicating that there were less variations in the responses of the respondents, showing also that the mean values of the items were valid. The data further indicates that the respondents varied in their responses more on the extent of utilization of strategic information management to re-engineer the computation/processing of student's results ( $\mathrm{SD}=1.24$ ) than on the provision of internet services for learning materials ( $\mathrm{SD}=0.49$ ).

\section{Research Question 2}

To what extent is strategic information management utilized in re-engineering research in federal universities in Nigeria?

The data for answering this research question and testing the hypothesis are presented in Table 2.

Data in Table 2 revealed that item 8 had a mean value of 3.75 indicating that the universities utilize IT to strategically re-engineer the provision of capacity building of staff for research work. Furthermore, six items had their mean values ranging from 2.95 - 3.46 indicating that the universities utilize strategic information management to re-engineer those research-based items to a moderate extent. Three items had mean values ranged from 2.03 - 
2.48 showing that the universities utilize strategic information management to re-engineer these items to a little extent.

Table 2 also revealed that 6 items had their f-calculated less than the f-table value (3.09), showing that for those items, the null hypothesis of no significance was accepted, while it was rejected for the remaining 4 items whose f-calculated values were greater than the f-table values.

The Table also showed that the standard deviation of the items ranged from $0.86-1.24$ which is a low range of values, indicating that there were less variations in the responses of the respondents, showing also that the mean values of the items were valid. The data further indicates that the respondents varied in their responses more on the extent of utilization of strategic information management to re-engineer collaboration with foreign researchers (SD $=1.24)$ than on publishing of research products $(\mathrm{SD}=$ $0.86)$.

\section{Research Question 3}

To what extent is strategic information management utilized in re-engineering University administration in federal universities in Nigeria?

Data for answering the research question and testing the hypothesis are presented in Table 3.

Table 3 shows that item 8 had a mean value of 3.57 indicating that the universities utilize IT to strategically re-engineer the dissemination of information among staff and students to a great extent. Data in the table further shows that the remaining eight items had their mean values ranging from 3.22 - 3.49 indicating that the universities utilize strategic information management to re-engineer those university administration-based items to a moderate extent.

Table 3 further revealed that seven items had their f-calculated less than the f-table value (3.09), showing that for those items, the null hypothesis of no significance was accepted, while it was rejected for the remaining two items whose f-calculated values was greater than the f-table values.

The Table also showed that the standard deviation of the items ranged from $0.86-1.25$ which is a low range of values, indicating that there were less variations in the responses of the respondents, showing also that the mean values of the items were valid. The data further indicates that the respondents varied in their responses more on the extent of utilization of strategic information management to re-engineer the provision of new relationships with clients of the institution ( $\mathrm{SD}=1.25$ ) than on the dissemination of Information among staff /students (SD = $0.86)$.

\section{Discussion of Findings}

Data collected regarding the extent to which strategic information management is utilized in re-engineering teaching and learning revealed that admission services are re-engineered to a large extent in the universities through strategic information management to a large extent. Other teaching and learning activities like production of learning aids/objects, production and presentation of lecture notes, Provision of student registration services, Improvement of the quality of academic work and substantial shortening of time needed to develop, produce, and deliver products and services are re-engineered to a moderate extent. Table 1 further revealed that vital teaching and learning activities like carrying out and submission of academic assignments, computation/processing of student's results, and the use of ICTs in teaching are re-engineered through strategic information management to a little extent. This later finding may be part of the reason why the universities are not yet satisfied with the results of information management despite the huge investments made. The vital activities of effective teaching and learning which is a major objective of university education, has not been given a strategic attention through information management. Hence, the assertion of O’Brien [5] that using information technology to improve an organization's operations can have many strategic effects. Investments in information technology can help make an organization's operations substantially more efficient. Improvements to its business processes could enable a company to cut costs dramatically and improve the quality and delivery of its products and services.

Table 2 shows data collected on the extent to which strategic information management is utilized in re-engineering research in federal universities in Nigeria. The data revealed that to a great extent, the provision of capacity building of staff for research work through strategic information management has been re-engineered. Other research-support activities such as provision of internet services for research works, provision of conducive environments for scientific researches, provision of library services for researches, publishing of research products, provision of scientific laboratory equipment/ resources, and development of research proposals/teams have been re-engineered to moderate extent through strategic information management. Creation of virtual organizations for academic and research works, collaboration with foreign researchers, and development of new unique markets for research products are research-support activities re-engineered through strategic information management to a little extent. According to Choo [14] information that has strategic value emerges out of the idea of information as an organizational resource and the related concept of competitive intelligence or environmental scanning. Thus, the information held in corporate databases may have strategic value in identifying 
new market opportunities or may in itself constitute new information products. Such new opportunities and new products are strategic in the sense that they aid the competitive position of the organization. Again, an organization may scan the business environment for market opportunities, for threats to present competitive positions, for potential replacement products and services for those currently marketed, and for potential acquisitions. New products have recently been marketed to enable firms scan the online databases and internet resources for competitive intelligence. Such information is strategic information and the systems designed to acquire, store, organize and make available for use, such information are strategic information systems.

Findings on research question 3 showed that on the extent to which strategic information management is utilized in re-engineering university administration in federal universities in Nigerian, information technology is used to re-engineer the disseminate information among staff/students to a great extent, while the promotion of administrative objectives, provision of new relationships with clients of the institution, discouragement of clients from switching to other institutions, re-engineering of administrative operations, institution of unique institutional reformations/innovations, capturing and keeping of administrative records, involvement of IT products in decision making, and creation of security networks within the institution are re-engineered through strategic information management to a moderate extent. According to McGee and Prusak [15], the return on investment for information resources occurs when the resources enhance the effectiveness and/or the efficiency of the organization in carrying out its mission. Strategic Information Resource Management Planning (SIRMP) is a process for identifying and prioritizing IT projects based on an organizations business strategy. Therefore, if the objectives or aims of the administration of the universities are not to a large extent re-engineered or promoted through strategic information, the effect of the enormous investments on information resources in the institutions will not be felt.

On the hypothesis tested, the study revealed that there were no significant differences in the mean ratings of the responses of the information managers from the universities on the extent to which strategic information is used to re-engineer six items on teaching and learning, six items on research, and seven items on university administration. However, data on the hypothesis tested further shows that the hypothesis was rejected on five items on teaching and learning, four items on research, and two items on university administration. The implication of these findings is that for the 19 items where the hypothesis was accepted, despite the difference in the institutions, their opinions were not significantly influenced. Their opinions however, were significantly influenced on 11 items on the extent to which to those items are re-engineered through strategic management.

\section{Conclusion}

A strategic information system is any kind of information system that helps an organization gain a competitive advantage, reduce competitive disadvantages, or meet other strategic enterprise objectives. University education is directed by distinct objectives, and fulfilling these objectives demands a re-engineering through strategic information management. Higher education institutions, Nigerian universities inclusive, have invested heavily in business process reengineering, leveraging information technology to improve services and reduce costs. However, despite this enthusiasm and heavy investment, the universities have never been able to achieve the kind of result they desired. Therefore this paper assessed the extent to which Nigerian universities utilize strategic information management to re-engineer the academic processes for better results. The findings of the study revealed that to a great extent, many necessary and relevant academic, research and administrative processes have not been re-engineered through strategic information management in the universities. This lapse in the operations in the universities is likely to be the reason why the advantages accruing from strategic information management have not been fully reaped.

\section{Recommendations}

Based on the findings of this study, the following recommendations were made:

1). The university administrators should try as possible to ensure that the investments on resources and information technology in the institutions are to a great extent commensurate with the expected results, through the re-engineering of academic processes through strategic management.

2). The administrators of the universities should ensure that the right and relevant technologies required in the re-engineering processes through strategic management are put in place for better results.

3). The information managers in the universities should intensify their in efforts in the activities and processes identified in this study whose extent to which they are re-engineered through strategic information management are still low.

\section{REFERENCES}

[1] T. Yi-Ming and C. Liang-Cheng, "Dynamic Interactive Framework to Link Business Intelligence with Strategy,” International Journal of Information Technology and Management, Vol. 6, No. 1, 2007, pp. 23-39. 
http://dx.doi.org/10.1504/IJITM.2007.011905

[2] M. A. Shirazi and J. Soroor, “An Intelligent Agent-Based Architecture for Strategic Information System Applications," Knowledge-Based Systems, Vol. 20, No. 8, 2007, pp. 726-735.

http://dx.doi.org/10.1016/j.knosys.2006.10.004

[3] K. F. Pun, C. K. Sankat and M. R. Yiu, "Towards Formulating Strategy and Leveraging Performance: A Strategic Information Systems Planning Approach,” International Journal of Computer Applications in Technology, Vol. 28, No. 2, 2007, pp. 128-139. http://dx.doi.org/10.1504/IJCAT.2007.013350

[4] T. Jitpaiboon and S. A. Kalaian, "Impacts of IS Dependency on IS Strategy Formulation,” International Journal of Information Systems and Change Management, Vol 1, No. 2, 2006, pp. 187-201.

[5] J. A. O’Brien, "Management Information Systems. Managing Information Technology in the E-Business Enterprise," 5th Edition, Irwin McGraw-Hill, New York City, 2002.

[6] W. T. Geer, “Aligning Technology with Strategic Objectives in Higher Education,” 2013. http://www.thecagroup.org/strategic.pdf

[7] W. Massy, "Objectives and Success Measures for Higher Education,” 2013. net.educause.edu/ir/library/pdf/ff0910s.pdf

[8] J. Ojango and O. Mwai, "Objectives of Higher Education-A Challenge to Fulfill,” 2013. http://agtr.ilri.cgiar.org/index.php?option=com_content\& view=article\&id=277\&Itemid=324

[9] Business Dictionary, 2013.

http://www.businessdictionary.com/definition/reengineeri ng.html\#ixzz2ahj4D2aF

[10] Hammer \& Champy, "Business Efficiency: IT Can Help Paint a Bigger Picture, Financial Times, Featuring Ian Manocha,” Lynne Munns and Andy Cross, 1993.

[11] M. Abdous and W. He, “A Framework for Process Reengineering in Higher Education: A Case Study of Distance Learning Exam Scheduling and Distribution,” USA Old Dominion University, Norfolk, 2008.

[12] H. Davenport and E. Short, “The New Industrial Engineering: Information Technology and Business Process Redesign,” Sloan Management Review, Vol. 31, No. 4, 1990, pp. 11-27.

[13] E. Adewumi, "The Year 2000 and Beyond: Practical Demonstration of Distributed Processing Concept in a Campus-Wide Link,” The Advance MIS Conference, ATMAN LIMITED, Nigeria 2000.

[14] C. I. Choo, "Special Issue on Environmental Scanning and Competitive Intelligence," Information Research, Vol. 7, No. 1, 2001, pp. 67-69.

[15] J. McGee and L. Prusak, "Managing Information Strategically,” Prentice Hall, Upper Saddle River, 2003. 